ESTABELECIMENTO DE ENSINO REMUNERADO - NATUREZA - EXERCICIO, POR FUNCIONARIO PUBLICO, DAS FUNÇÕES DE DIREÇÃO OU GERENCIA

- A vista da expressa proibiçäo contida nos itens $I I$ eVI do art. 226 do Estatuto dos Funcionários, é patente a incompatibilidade para exercer, o funcionário público, funçōes de gerência ou direção em estabelecimentos de ensino remunerado, ou ter parte em sociedades que o explorem.

\title{
DEPARTAMENTO ADMINISTRATIVO DO SERVIÇO PÚBLICO
}

\section{PROCESSO N. $1.023-44$}

O ato de ministrar ensino, evidentemente, não é, em si mesmo "ato do comércio", revestindo-se, ao invés, do caráter típico de prestação de um serviço público. Daí o determinarem alguns diplomas, como o faz a lei orgânica do ensino secundário, que aos estabelecimentos de ensino cabem "deveres e responsabilidades inerentes ao serviço público" (Decreto-lei n. 4.239 , de 9-4-42, art. 70).

Da mesma forma as emprêsas que exploram serviços concedidos - ou "utilidades públicas", seguindo a terminologia anglo-americana - também têm por finalidade a execução de atos que constituem, tìpicamente, serviço público (Jk̀ze, Los Principes Généraux du Droit Administratif, 13." Ed., Paris, 1914, p. 429; Donato Donati, Principii Generali di Diritto Amministrativo • Scienza dell'Amministraxicne, Padova, 1932 : UGo FORT, Diritto Amministrativo, vol. I, Nápoles, 1931, p. 264).

Não há recusar no entanto, a estas emprêsas - como não se poderá negar àquelas - o caráter de estabelecimentos comerciais.

E' isso, em verdade, o que têm entendido as nossas egrégias Côrtes de Justiça, para quem os colégios estão acobertados pelas prescriçōes que protegem o "fundo mercantil", equiparando-se, assim, às casas comerciais (Cfr. rerbi gratia, Acórdão da 4." Câmara do Tribunal de Apelação do Distrito Foderal, Diário da Justiça, de 20-9-43, p. 3.622).

E a racão disso - como esclarece SPENCER VAMPRÉ, a propósito de hipótese semelhante - decorre da circunstância de ser remunerado o serviço que êsses estabelecimentos prestam e que lhes outorga o caráter de comercialidade, malgrado o fim político, esportivo, religioso, etc. que possam ter (SPENCER VAMPRÉ, Tratado Elementar de Direito Comercial, F. Briguiet 6 Comp., vol. III, p. 61, nota 11).

Por outro lado, a Consolidação das Leis do Trabalho, aprovada pelo Decreto-lei $n^{\circ} 5.452$, de $1-5-43$, dispöe, no seu art. 352 , \& $1 .^{\circ}$, in verbia :

"Gob a denominação geral de atividades industriais e comerciais compreendem-se, além de outras que venham a ser determinadas em portaria do Ministro do Trabalho, Indústria e Comércio, as exercidas :

i) pelos estabelecimentos de ensino remunerado, etc... 
Ora, o direito administrativo não constitui um ramo jurídico inteiramente independente do sistema geral do direito positivo, valendo-se, ao invés disso, dos conceitos e fórmulas dos outros ramos do direito, dos quais freqüentemente se socorre, pelo fenômeno comum na ciência jurídica, que alguns autores italianos, como MANzINI, denominam "finvio ricettivo". Isto porque, segundo adverte o nosso Carlos MaximIlano, o direito objetivo não é um conglomerado caótico de preceitos: constitui vasta unidade, organismo regular, sistema, conjunto harmônico de normas coordenadas, em interdependência metódica, embora fixada cada uma em seu lugar próprio (CARLos Maxmllano, Hermenêutica e Aplicação do Direito, Edição da Livraria do Globo, Pôrto Alegre. 1925, p. 134). "É lo spirito oggetivo di tutto il diritto che bisogna porre in essere", diz Caldara (Interpretazione delle Leggi, Soc. Ed. Libraria, Milão, 1908, p. 243).

E', portanto, evidente, à vista da expressa proibiçäo contida nos itens II $\theta$ VI do art. 226 do E. F., a incompatibilidade para exercer o funcionário público funçōes de direção ou gerência em estabelecimentos de ensino remunerado, ou ter parte em sociedades que o explorem.

A rigor, portanto, o servidor de que trata o presente processo, tendo firmado o contrato junto, incidiu na proibição legal e seria passivel da penalidade correspondente. $O$ equívoco ou a boa-fé do servidor não poderia, segundo os autores mais credenciados, ter qualquer influência no sentido de excluir a configuração da falta disciplinar, havendo mesmo quem sustente e advogue, como NÉzard, que o êrro de direito o a ignorância da lei, em se tratando de funcionários, constituem circunstâncias agravantes e não atenuantes, como no direito penal. A intenção criminosa não interessa: basta, como nas contravençōes, um fato material contrário à lei (Cfr. Marcelo CaETano, Do Poder Disciplinar, Imprensa da Universidade, Coimbra, 1932, p. 56).

A aplicação de tais princípios ao caso em aprêço redundaria, porém, em grave injustiça. E - como já foi assinalado - o direito não pode servir do instrumento ou pretexto à violação da harmonia social, de que é fator precípuo. O seu objetivo primacial é a instituição da ordem - ordinatio rationis - e ordem não pode həver onde falte justiça.

A atitude honesta e digna do servidor em aprêço, que, ao ter notícia da interpretação dada aos dispositivos estatutários, apressou-se a dirigir-se às autoridades superiores, exibindo o contrato assinado e consultando-as sôbre a legitimidade do ato praticado, não é das que reclamam pena ou reprimenda. Seria injusta e, portanto, injurídica a sanção disciplinar que se the impusesse.

Por outro lado, os dispositivos estatutários não são rea:mente muito claros, no tocante à matéria, podendo gerar dúvidas e alicerçar a convicção da licitude do ato praticado. E não seré contrário pos princípios superiores da justiça, seguir-se a orientação adotada, em hipótese semelhante, pelo Supremo Tribunal Administrativo de Portugal que "em caso duvidoso sôbre interpretação de uma disposiçāo legal, menos clara" houve por bem deixar de aplicar pena.

E' também o que se impöe no presente caso.

Restitua-se à repartição de origem, para arquivamento, ficando, porém, o servidor obrigado a providenciar a imediata rescisão do contrato que firmou.

Distrito Federal, 10 de fevereiro de 1944. - Lúcio Bittencourt, D.D. 